\title{
Third International Workshop on Major Genes and QTL in Sheep and Goats
}

\author{
8-11 December 2003, Toulouse, France
}

\section{GUEST EDITOR}

Loys BODIN - INRA Toulouse

\section{ORGANISING COMMITTEE}

François BOCQUIER - ENSA Montpellier Loys BODIN - INRA Toulouse

Edmond CRIBIU - INRA Jouy-en-Josas
Stéphane FABRE - INRA Tours Frédéric LANTIER - INRA Tours

Philippe MULSANT - INRA Toulouse 
Genet. Sel. Evol. 37 (Suppl. 1) (2005)

(C) INRA, EDP Sciences, 2004

DOI: $10.1051 / \mathrm{gse}: 2004039$

\section{FOREWORD TO THE INTERNATIONAL WORKSHOP ON MAJOR GENES AND QTL IN SHEEP AND GOATS}

This is the third international meeting dealing with major genes in small ruminants. The first was held in Armidale (NSW, Australia) in 1980, just after the discovery of the Booroola gene by B. Bindon and L. Piper. The discovery of a gene having such a large effect on ovulation rate and prolificacy in sheep was totally unsuspected at this time and a number of research teams all over the world concentrated their efforts to study its effects and identify the causal mutation. About 20 years were finally needed to obtain this information, which opened a new approach to the physiological regulation of reproduction.

The second meeting was organised in 1990 in Toulouse along the same lines. Although its main concern was the Booroola gene, other major genes influencing ovulation in sheep were also considered. Indeed, an increasing amount of evidence demonstrated that, on the contrary to the current opinion in quantitative genetics laboratories before 1980, prolificacy is not always controlled by a very large number of genes each exhibiting a very small effect, but may also be influenced by genes with large effects, generalising the Booroola situation to other populations.

Since then, mixed inheritance was also found for other production traits such as body conformation, seasonality or milk composition. However, the major evolution has been the inexpensive large-scale access to molecular genetic information, using PCR, microsatellites and SNP technologies. QTL detection experiments are performed in all domestic species, including sheep and goats, and the identification of genes having an average effect on the performance trait variability is now possible. The utilisation of these polymorphisms should also be a great help for a better management of populations, either through the selection of breeders or through the preservation of genetic diversity.

This third meeting on major genes and QTL in sheep and goats was a unique occasion for the researchers involved in this area of Animal Science to present their latest results, exchange their experiences and progress in the organisation of scientific co-operation.

Jean Michel ELSEN

INRA, Scientific Director for Animal Production 